\title{
Long term results of intraoperative mitomycin C in the treatment of recurrent pterygium
}

\author{
Leonardo Mastropasqua, Paolo Carpineto, Marco Ciancaglini, Pier Enrico Gallenga
}

\begin{abstract}
Aim-The study was designed to evaluate the long term results of intraoperative mitomycin $\mathbf{C}$ in patients with one recurrence of pterygium.

Methods-In 45 white patients with one recurrence of pterygium the 'bare sclera technique' was performed and a sterile sponge soaked in a $0.2 \mathrm{mg} / \mathrm{ml}(0.02 \%)$ mitomycin $\mathbf{C}$ solution was placed intraoperatively on the sclera for 3 minutes. The control group underwent surgical excision only. Recurrences were analysed by the $\chi^{2}$ test and the method of Kaplan-Meier (life table analysis); the difference between survival curves was tested by the log rank test. The $\chi^{2}$ test with Yates's correction or Fisher's exact test were used to analyse the difference in complications and side effects between the two groups.
\end{abstract}

Results-After a mean postoperative follow up of 34.55 (SD 13.70) months, 6 recurrences $(12 \cdot 5 \%)$ were observed in the mitomycin $C$ treated patients and 16 $(35 \cdot 6 \%)$ in the control patients $(p=0 \cdot 027)$. The 24 and 48 month life table success rates were $89 \%$ and $83 \%$ in the mitomycin $C$ treated group and $66 \%$ and $63 \%$ in the control group, respectively $(p=0.022)$. No severe side effects appeared during follow up. Superficial punctate keratitis appeared in the early postoperative period in only seven mitomycin $C$ treated eyes $(15 \cdot 5 \%)$ $(p=0 \cdot 018)$.

Conclusion-This study confirms the efficacy of intraoperative mitomycin $\mathbf{C}$ in improving the success rate after recurrent pterygium surgical excision.

(Br f Ophthalmol 1996; 80: 288-291)

Mitomycin $\mathrm{C}$ is an antibiotic antineoplastic agent inhibiting RNA, DNA, and protein synthesis. Results and complications of the postoperative use of mitomycin $C$ eyedrops for prevention of recurrent pterygium were widely reported. ${ }^{1-14}$

Ophthalmologists have recently considered the effectiveness of the intraoperative use of mitomycin $C$ in pterygium surgery. ${ }^{15-17}$ Our previous study showed short term results to be encouraging in the treatment of recurrent pterygium. ${ }^{16}$

The aim of our study was to show the long term results of intraoperative administration of mitomycin $C$ in the surgical treatment of recurrent pterygium and to evaluate long term complications.

\section{Materials and methods}

From January 1991 to December 1994, 90 white patients (90 eyes) undergoing surgical treatment for recurrent pterygium were selected for a prospective, randomised, masked study.

Inclusion criteria were first recurrence of pterygium and pterygium growth on the cornea for a minimum of $2 \mathrm{~mm}$ from the limbus. Pterygium growth on the cornea was measured with Castroviejo compasses.

The patients were divided at random in two age and sex matched groups: group 1 consisted of 45 patients ( 28 males, 17 females; mean age 40.8; range 21-59 years) with group 2 also of 45 patients (27 males, 18 females; mean age $40 \cdot 7$, range 21-61 years) (Table 1 ).

All of the surgeries were performed by the same surgeon (LM) under local anaesthesia. Approximately $0.4 \mathrm{ml}$ of mepivacaine (Carbocaine) $1 \%$ were injected under the pterygium to elevate it into its attachment to the cornea.

The head of the pterygium was grasped with toothed forceps. Dissection of the pterygium was started using a Beaver 64 surgical blade about $0.5 \mathrm{~mm}$ ahead of the pterygium apex and carried down clearly to the limbus.

In group 1 we added intraoperative administration of mitomycin C (Kyowa Hakko Kogyo Co Ltd, Tokyo) to the pterygium surgery.

A sterile sponge $(5 \times 5 \mathrm{~mm})$ was soaked in a sterile container containing $2 \mathrm{ml}$ of a $0.02 \%$ mitomycin C solution $(50 \mathrm{mg}$ of $4 \%$ mitomycin $C$ powder mixed with $10 \mathrm{ml}$ of balanced salt solution). By measuring the amount of solution remaining in the container it was possible to state that after soaking in the sponge there were $0.2 \mathrm{ml}$ of solution.

After the pterygium head was detached from the cornea, the soaked sponge was placed under the conjunctival flap containing the pterygium, on the sclera. After 3 minutes the sponge was removed and the site was rinsed thoroughly with $10 \mathrm{ml}$ of balanced salt solution.

Surgery was completed with pterygium excision ('bare sclera technique'). The subconjunctival tissue superficial to the sclera was cleaned towards the insertion of the medial rectus muscle and triangular excision of the pterygium and conjunctiva, including the

Table 1 Demographic and preoperative data

\begin{tabular}{lll}
\hline Preoperative & $\begin{array}{l}\text { Mitomycin } C \\
\text { treated group }\end{array}$ & Control group \\
\hline $\begin{array}{l}\text { No } \\
\begin{array}{l}\text { Age (years) } \\
\quad \text { Mean (SD) }\end{array}\end{array}$ & 45 & 45 \\
$\begin{array}{l}\text { Sex (\% male) } \\
\text { Follow up (months) } \\
\quad \text { Mean (SD) }\end{array}$ & $\begin{array}{l}40 \cdot 8(12 \cdot 1) \\
\text { 62.2 }\end{array}$ & $40 \cdot 7(11 \cdot 4)$ \\
\hline
\end{tabular}

Ophthalmology

D'Annunzio, Chieti,

L Mastropasqua

P Carpineto

M Ciancaglin 30 November 1995
}

(1)




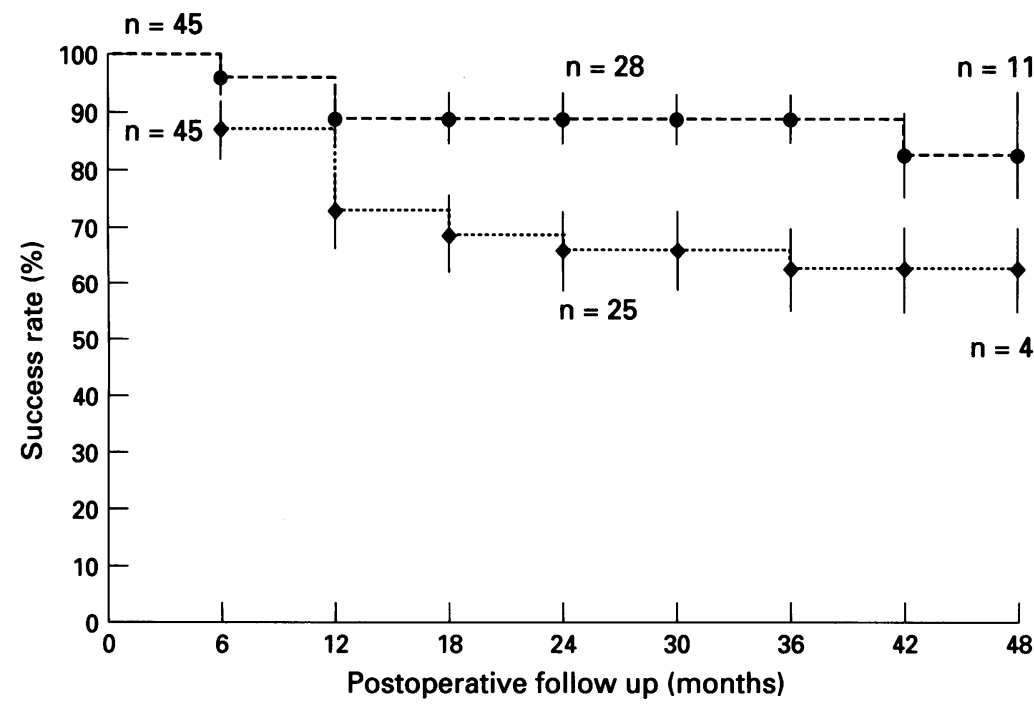

--๑-. MMC treated group

Figure 1 Survival curve for the mitomycin $C$ treated group and the control group. Success rate (SE) versus postoperative follow up time (log rank test $=5 \cdot 31, p=0.022)(n=$ no of patients).
All patients were examined with a Zeiss SL30 slit-lamp to evaluate the recurrence of pterygium and the appearance of complications (conjunctival, corneal and scleral changes, anterior chamber reaction, intraocular pressure changes).

Complications were graded as absent, light, and severe $(-,+,++)$ according to the severity of the clinical findings.

The patients were questioned specifically about side effects (pain, photophobia, and foreign body sensation). Side effects were also graded $(-,+,++)$ according to patients' discomfort.

Statistical analysis was performed using Student's $t$ test to compare the follow up of the two groups and the ages of patients experiencing recurrence between the two groups. Success rates were calculated employing the $\chi^{2}$ test and the life table analysis to calculate survival curve by the Kaplan-Meier method; the difference between survival curves was tested by the log rank test. The success rates calculated by the Kaplan-Meier method differ from those of cross sectional analysis because they represent the cumulative probability of success based only on patients who have not yet failed or dropped out and they exclude a patient from further analysis once that patient has failed. ${ }^{18}$

The $\chi^{2}$ test with Yates's correction or Fisher's exact test was used to analyse the difference in adverse reactions between the two groups.

Informed consent for participation in the study was obtained from all patients before their enrolment.

in all cases the diagnosis of pterygium was operative period all patients were examined weekly for the first month and then monthly, by a clinician who was masked to the patient treatment.

Recurrence was diagnosed when a fibrovascular growth, in the position of the previously excised pterygium, crossing the limbus and extending onto the cornea for any distance, occurred. In case of recurrence, follow up was stopped at the time of the diagnosis.

Table 2 Life table analysis

\begin{tabular}{|c|c|c|c|c|c|c|c|c|c|c|}
\hline \multirow{2}{*}{$\begin{array}{l}\text { Follow up } \\
\text { (months) }\end{array}$} & \multicolumn{2}{|c|}{ No of patients } & \multicolumn{2}{|c|}{ Recurrences } & \multicolumn{2}{|c|}{$\begin{array}{l}\text { End of follow up } \\
\text { (no of patients) }\end{array}$} & \multicolumn{2}{|c|}{$\begin{array}{l}\text { Cumulative } \\
\text { probability of success }\end{array}$} & \multicolumn{2}{|l|}{$S E$} \\
\hline & $M M-C$ & Control & $M M-C$ & Control & $M M-C$ & Control & $M M-C$ & Control & $M M-C$ & Control \\
\hline $\begin{array}{c}0-6 \\
7-12 \\
13-18 \\
19-24 \\
25-30 \\
31-36 \\
37-42 \\
43-48\end{array}$ & $\begin{array}{l}45 \\
42 \\
36 \\
31 \\
28 \\
23 \\
18 \\
11\end{array}$ & $\begin{array}{r}45 \\
38 \\
32 \\
28 \\
25 \\
22 \\
15 \\
4\end{array}$ & $\begin{array}{l}2 \\
3 \\
0 \\
0 \\
0 \\
0 \\
1 \\
0\end{array}$ & $\begin{array}{l}6 \\
6 \\
2 \\
1 \\
0 \\
1 \\
0 \\
0\end{array}$ & $\begin{array}{l}1 \\
3 \\
5 \\
3 \\
5 \\
5 \\
6 \\
9\end{array}$ & $\begin{array}{r}1 \\
0 \\
2 \\
2 \\
3 \\
6 \\
11 \\
4\end{array}$ & $\begin{array}{l}0.96 \\
0.89 \\
0.89 \\
0.89 \\
0.89 \\
0.89 \\
0.83 \\
0.83\end{array}$ & $\begin{array}{l}0.87 \\
0.73 \\
0.69 \\
0.66 \\
0.66 \\
0.63 \\
0.63 \\
0.63\end{array}$ & $\begin{array}{l}0.029 \\
0.046 \\
0.046 \\
0.046 \\
0.046 \\
0.046 \\
0.074 \\
0.074\end{array}$ & $\begin{array}{l}0.051 \\
0.067 \\
0.069 \\
0.072 \\
0.072 \\
0.077 \\
0.077 \\
0.077\end{array}$ \\
\hline
\end{tabular}

$\mathrm{MM}-\mathrm{C}=$ mitomycin $\mathrm{C}$.

Table 3 Complications and side effects $(-=a b s e n t,+=$ light, $++=$ severe $)$

\begin{tabular}{|c|c|c|c|c|c|c|}
\hline & \multicolumn{3}{|c|}{ Mitomycin C treated group } & \multicolumn{3}{|l|}{ Control group } \\
\hline & - & + & ++ & - & + & $\overline{++}$ \\
\hline $\begin{array}{l}\text { Complications } \\
\text { Superficial punctate keratitis }{ }^{\star} \\
\text { Side effects }\end{array}$ & $38\left(84^{\circ} 4 \%\right)$ & $7(15 \cdot 6 \%)$ & 0 & $45(100 \%)$ & 0 & 0 \\
\hline $\begin{array}{l}\text { Ocular pain } \\
\text { Photophobia }\end{array}$ & $\begin{array}{l}18(40 \%) \\
28(62 \cdot 2 \%)\end{array}$ & $\begin{array}{l}27(60 \%) \\
17(37 \cdot 8 \%)\end{array}$ & $\begin{array}{l}0 \\
0\end{array}$ & $\begin{array}{l}21(46 \cdot 7 \%) \\
31(68 \cdot 9 \%)\end{array}$ & $\begin{array}{l}24(53 \cdot 3 \%) \\
14(31 \cdot 1 \%)\end{array}$ & $\begin{array}{l}0 \\
0\end{array}$ \\
\hline
\end{tabular}

^Fisher's exact test, $\mathrm{p}=0.018$. 
difference between the groups was statistically significant $(p=0.027)$.

The data of life table analysis of both groups are shown in Table 2. Survival curves are shown in Figure 1.

In group 1 all recurrences except one occurred during the first 10 months. One recurrence was seen after 40 months of follow up.

In group 2 the highest incidence of recurrence was seen within the first 18 months. In group 1 the mean age of patients experiencing recurrence of pterygium was $30.83(7.73)$ years (range 21-42 years) and in the control group it was 39.94 (9.36) years (range 21-53 years). The difference was statistically significant $(p=0 \cdot 047)$.

Complications and side effects were observed only during the first 2 weeks of follow up. In the mitomycin $C$ treated group, the only complication was light superficial punctate keratitis. Side effects were ocular pain and photophobia in both groups (Table 3). After 4 weeks of follow up in one mitomycin $C$ treated eye an area of avascularity in the site of the previous excised pterygium was detected; nevertheless no corneal changes or subjective symptoms were reported.

\section{Discussion}

Mitomycin C is an antibiotic antineoplastic agent, activated to an alkylating agent in tissues: it inhibits RNA DNA dependent synthesis, preventing cellular division and duplication; it has therefore been used to prevent fibroblast proliferation and scarring after filtration surgery. Since 1962 mitomycin C eyedrops have been used to prevent recurrence of pterygium after surgery, on the basis that the fibrovascular reaction in the pathogenesis of pterygium is the result of a chronic irritation. ${ }^{19}$ Recently, the possibility of mast cells contributing to the pathogenesis of pterygia has been supposed. ${ }^{20}$

The use of mitomycin $\mathrm{C}$ eyedrops after pterygium surgery seemed to be an effective and safe method to prevent recurrence of pterygium, in fact recurrence rates of between $1.4 \%$ and $13 \%$ have been published. 3562122 Unfortunately, topical mitomycin has been reported to cause a variety of complications. Sometimes complications are very severe, such as symblepharon, ${ }^{6}$ scleral ulceration ${ }^{10}$ and necrosis, ${ }^{11}$ secondary glaucoma, and corneal perforation. ${ }^{13}$ It is not acceptable that the surgical excision of a generally benign pathology such as pterygium should cause such serious complications.

Some authors have proposed the use of low dose mitomycin $C(0.01 \%)$ after pterygium excision. ${ }^{23}$ A prospective, multicentre, randomised comparison has begun of recurrence rates after pterygium excision and intraoperative $0.04 \%$ mitomycin $C$ for 3 minutes versus other techniques. ${ }^{15}$

Since 1991 we have used intraoperative mitomycin $\mathrm{C}$ in patients with one recurrence of pterygium undergoing surgical excision. Encouraging results were shown in our preliminary study. ${ }^{16}$ The long term results confirm the efficacy of this kind of therapy to prevent recurrence of pterygium: only six recurrences were detected in the mitomycin C treated group as against 16 recurrences in the control group $(p=0.027)$. Life table analysis showed a success rate of $89 \%$ and $83 \%$ in the mitomycin C treated group and of $66 \%$ and $63 \%$ in the control group after 24 and 48 months of follow up, respectively (Fig 1).

The recurrence rate in the control group is similar to those found in previous studies on bare scleral closure (24-68\%). ${ }^{24-29}$

Five out of six $(83.3 \%)$ and 12 out of 16 $(75 \%)$ recurrences occurred within the first year in the mitomycin $C$ treated group and control group, respectively. Our data confirm those of Hirst et $a l^{30}$ who affirm that a 12 month follow up is able to identify more than $97 \%$ of recurrences. In the mitomycin C treated group no patient who has not yet experienced pterygium recurrence has a follow up shorter than 1 year.

The mean age of the patients experiencing recurrence of pterygium differs significantly between the two groups $(p=0.047)$. In the mitomycin $\mathrm{C}$ treated group failures were seen only in young people (mean age $30.83(7.73)$; range 21-42 years). In controls recurrences were seen mostly, but not exclusively, in young people (mean age 39.94 (9.36); range 21-53 years). These data seem to show that in younger people the inhibiting effect of mitomycin $\mathrm{C}$ on fibroblast proliferation may be less effective in preventing fibrovascular reaction.

Although a relatively small number of patients was treated to detect complications with a very low rate, a very encouraging fact emerging from our study was the absence of the unpleasant complications and side effects reported for prolonged mitomycin $\mathrm{C}$ eyedrop therapy.

The exposure of the sclera for no more than 3 minutes, the accuracy of cut of the sterile sponge, and the diluted mitomycin $\mathrm{C}$ solution $(0.2 \mathrm{mg} / \mathrm{ml}$ of mitomycin $\mathrm{C}$ powder in balanced salt solution) all contributed to the standardisation of the method.

1 Spires R. Postoperative instillation of mitomycin eye drops in the treatment of primary pterygium. $\mathcal{F}$ Ophthalmic Nurs Technol 1991; 10: 15-7.

2 Singh G, Wilson MR, Foster CS. Long-term follow-up study of mitomycin eye drops as adjunctive treatment of pterygia and its comparison with conjunctival autograft transplantation. Cornea 1990; 9: 331-4.

3 Singh G, Wilson MR, Foster CS. Mitomycin eyedrops as treatment for pterygium. Ophthalmology 1988; 95: 813-21.

Simona F, Anastasi-Forni C, Benedetti C, Failla FG, Ross FM, Meyer U. Mitomycine therapy after (herapy after excision of pterygium. Klin Monatsbl Augenheilkd 1994; 204:

Chayakul V. Prevention of recurrent pterygium by mitomycin C. 84 Tag Dtsch Ophthalmol Ges Aachen Fortschr Ophthalmol 1987; 84: 422-4.

6 Hayasaka S, Noda SN, Yamamoto Y, Setogawa T. Postoperative instillation of low-dose mitomycin $C$ in the treatment of primary pterygium. Am $\mathcal{F}$ Ophthalmol 1988; 106: $715-8$.

7 Hayasaka S, Noda SN, Yamamoto Y, Setogawa T. Postoperative instillation of mitomycin $C$ in the treatment of recurrent pterygium. Ophthalmic Surg 1989; 20: 580-3.

8 Mahar PS, Nwokora GE. Role of mitomycin C in pterygium surgery. Br f Ophthalmol 1993; 77: 433-5.

9 Yamanouchi U. A case of scleral calcification due to mitomycin C instillation after pterygium operation. Folia Ophthalmol fpn 1978; 29: 1221.

10 Dunn JP, Seamone CD, Ostler HB, Nickel BL, Beallo A. Development of scleral ulceration and calcification after pterygium excision and mitomycin therapy. $A m \mathcal{f}$ Ophthalmol 1991; 112: 343-4. 
11 Hara T, Hara T. Simple pterygium surgery with an electric drill and mitomycin-C eye drops. Afr-Asian 7 Ophthalmol 1982; 1: 160-3.

12 Gupta S, Basti S. Corneoscleral, ciliary body, and vitreoretinal toxicity after excessive instillation of mitomycin $\mathrm{C}$ Am f Ophthalmol 1992; 114: 503-4.

13 Rubinfeld RS, Pfister RR, Stein RM, Foster CS, Martin NF, Stoleru S, et al. Serious complications of topical mitomycin-C after pterygium surgery. Ophthalmology 1992; 99: 1647-54.

14 Sugar A. Who should receive mitomycin-C after pterygium surgery? [Editorial]. Ophthalmology 1992; 99: 1645-6.

15 Kloess MP, Yee RW, Hopp LM. Mitomycin C after pterygium excision. Ophthalmology 1993; 100: 292-3.

16 Mastropasqua L, Carpineto P, Ciancaglini M, Lobefalo L Gallenga PE. Effectiveness of intraoperative mitomycin $C$ in the treatment of recurrent pterygium. Ophthalmologica 1994; 208: 247-9.

17 Frucht-Pery J, Ilsar M, Hemo I. Single dosage of mitomycin-C for prevention of recurrent pterygium: preliminary report. Cornea 1994; 13: 411-3.

18 Fisher LD, Van Belle G. Biostatistics. A methodology for the health sciences. New York: J Wiley and Sons, 1993: 801-22.

19 Hill JC, Maske R. Pathogenesis of pterygium. Eye 1989; 3: 218-26.

20 Butrus SI, Farooq Ashraf M, Laby DM, Rabinowitz AI, Tabbara SO, Hidayat AA. Increased numbers of mast cells in pterygia. Am $\mathcal{F}$ Ophthalmol 1995; 119: 236-7.
21 Chayakul V. Postoperative mitomycin-C eye drop and beta radiation in the treatment of pterygia. $\mathcal{f}$ Med Assoc Thai radiation in the

22 Yamanouchi U, Mishima K. Eye lesions due to mitomycin $\mathrm{C}$ instillation after pterygium operation [in Japanese]. Folia Ophthalmol fpn 1967; 18: 854-61.

23 Frucht-Pery J, Ilsar $M$. The use of low-dose mitomycin-C for prevention of recurrent pterygium. Ophthalmology 1994; 101: 759-62.

24 De Keizer RJW. Pterygium excision with or without postoperative irradiation, a double blind study. Doc Ophthalmol erative irradiation,

25 Youngson RM. Recurrence of pterygium after excision. $\mathrm{Br} \mathcal{F}$ Ophthalmol 1972; 56: 120-5.

26 Kaimbo K. Traitement chirurgical du ptérygion: 42 cas d'excision. f Fr Ophtalmol 1988; 11: 335-8.

27 Bahrassa F, Datta R. Postoperative beta radiation treatment of pterygium. Int 7 Radiat Oncol Biol Phys 1983; 9: 679-84

28 Walter WL. Pterygium surgery. An evaluation and discussion of various operative procedures with the description of a surgical technique. Am $\mathcal{f}$ Ophthalmol 1961; 51: of a sur. 50 .

29 Sebban A, Hirst LW. Pterygium recurrence rate at the Princess Alexandra Hospital. Aust NZ F Ophthalmol 1991; 19: 203-6.

30 Hirst LW, Sebban A, Chant D. Pterygium recurrence time. Ophthalmology 1994; 101: 755-8. 